Boyce, A. J., H. Shamon, K. E. Kunkel, and W. J. McShea. 2021. Grassland bird diversity and abundance in the presence of native and non-native grazers. Avian Conservation and Ecology 16(2):13. https://doi.org/10.5751/ACE-01944-160213

Copyright (C) 2021 by the author(s). Published here under license by the Resilience Alliance.

Research Paper

\title{
Grassland bird diversity and abundance in the presence of native and non-native grazers
}

Andy J. Boyce ${ }^{1,2}$, Hila Shamon ${ }^{1}$, Kyran E. Kunkel $^{3,4,5}$ and William J. McShea ${ }^{1}$

${ }^{1}$ Conservation Ecology Center, Smithsonian Conservation Biology Institute, Front Royal, VA U.S.A, ${ }^{2}$ Migratory Bird Center, Smithsonian Conservation Biology Institute, Washington DC., USA, ${ }^{3}$ Conservation Science Collaborative, ${ }^{4}$ University of Montana, ${ }^{5}$ Smithsonian Institution, U.S.A

ABSTRACT. Temperate grassland biomes are globally imperiled, and grassland birds are in precipitous decline as a result. The majority of North America's grassland birds breed on rangelands occupied by domestic cattle, but reintroductions of bison to restore evolutionary grazing patterns are increasingly common. Grassland landscapes in western North America have undergone drastic changes since millions of bison occupied this landscape, and the biodiversity effects of bison on modern rangelands remain poorly understood. Here, we test the biodiversity effects of native versus non-native grazers in the context of a highly diverse grassland bird community on the Northern Great Plains of North America. We compared the effects of 2 different grazing treatments common across the region on avian diversity: seasonally grazed and manually rotated domestic cattle, and year-round, free-moving bison. We also test whether estimated abundances of 11 grassland/steppe obligate songbirds differ between these two management regimes. We found roughly equivalent bird diversity, as measured by species richness and Shannon's diversity index, at sites occupied year-round by bison and seasonally by cattle. We also found no significant effect of grazer type on 9 of 11 grassland songbird species. The two exceptions were Grasshopper Sparrow and Vesper Sparrow, which were more abundant in bison pastures. Our results suggest that both native and nonnative grazers can create habitat for a highly diverse assemblage of grassland birds under grazer-specific management regimes.

\section{Diversité et abondance des oiseaux de prairie en présence d'herbivores indigènes et non indigènes}

RÉSUMÉ. Les biomes des prairies tempérées sont menacés à l'échelle mondiale et par conséquent, les oiseaux de prairie connaissent une diminution accélérée. La majorité des oiseaux de prairie d'Amérique du Nord nichent dans des pâturages occupés par du bétail domestique, mais les réintroductions de bisons visant à rétablir des modèles de pâturage évolutifs sont de plus en plus courantes. Les paysages de prairies dans l'ouest de l'Amérique du Nord ont subi des changements radicaux depuis que des millions de bisons les ont occupés, et les effets du bison sur la biodiversité des grands pâturages contemporains restent mal connus. L'objectif de la présente étude était de tester les effets sur la biodiversité des herbivores indigènes et non indigènes dans le contexte d'une communauté d'oiseaux de prairie très diversifiée dans les Grandes Plaines du Nord de l'Amérique du Nord. Nous avons comparé les effets de deux traitements de broutement différents, communs à toute la région, sur la diversité aviaire : le bétail domestique, broutant de façon saisonnière et soumis à une rotation manuelle, et le bison, qui se déplace librement toute l'année. Nous avons également vérifié si l'abondance de 11 espèces d'oiseaux chanteurs obligatoires des prairies et des steppes différait entre ces deux régimes de gestion. Nous avons trouvé une diversité d'oiseaux à peu près équivalente, mesurée par la richesse des espèces et l'indice de diversité de Shannon, dans les sites occupés toute l'année par les bisons et de façon saisonnière par le bétail. De plus, aucun effet significatif du type d'herbivores sur 9 des 11 espèces d'oiseaux chanteurs des prairies n'a été constaté. Les deux exceptions étaient le Bruant sauterelle et le Bruant vespéral, qui étaient plus abondants dans les pâturages de bisons. Nos résultats indiquent que les herbivores indigènes et non indigènes peuvent créer de l'habitat pour un assemblage très diversifié d'oiseaux de prairie, dans le cadre de régimes de gestion spécifiques aux herbivores.

Key Words: bison; cattle; conservation; Northern Great Plains; prairie; restoration; rewilding; songbird

\section{INTRODUCTION}

Temperate grassland ecosystems and their dependent species are among the most imperiled globally (Hoekstra et al. 2005, Henwood 2010). In North America, many grassland obligate species have been extirpated from large portions of their native range or are in rapid decline (Manning 1995). Grassland birds are the most rapidly declining avian guild, with some species experiencing population declines of more than $80 \%$ in the past 50 years (Sauer et al. 2017, Rosenberg et al. 2019). The greatest current threat to grassland birds in western North America is the conversion of native prairie to tilled farmland or anthropogenic infrastructure (Knopf 1994, Gage et al. 2016). Advances in farming practices, increasing scale of agriculture, crop subsidies, drought-tolerant crops, and increased demand for soy and biofuels are driving the loss of rangelands across the Great Plains (Wright and Wimberly 2013, Gage et al. 2016). This large-scale habitat conversion is driving rapid declines among grassland obligate species as a direct consequence of both habitat loss and fragmentation; a phenomenon that highlights the critical conservation value of remaining native grasslands (Knopf 1994, 
Tack et al. 2019). As such, there is high need to manage those grasslands to ensure maximum abundance and diversity of key grassland species.

Nearly all grasslands in the western US are managed as rangelands for production of domestic cattle. Managing rangelands for biodiversity and economic production means facilitating disturbance while preventing overgrazing damage to plants and soil. Managing grasslands for habitat heterogeneity has become recognized as an important value and goal because these ecosystems evolved in concert with high levels of stochastic disturbance which produced multi-scale heterogeneity. Fire, precipitation, and grazers are the primary ecological forces that produce plant heterogeneity in grassland systems (Fuhlendorf et al. 2012). However, precipitation is not manageable, and fire is not socially accepted as a management tool across large portions of the Great Plains (Sliwinski et al. 2018). Therefore, the restoration of evolutionary grazing patterns by large herbivores is the primary conservation tool available to promote ecosystem health and biodiversity (Fuhlendorf et al. 2018). Contemporary efforts to manage grazing for maximum heterogeneity on the mixed-grass prairie of the Northern Great Plains generally focus on one of two methods: 1) grazing cattle via rotation through a series of pastures to mimic evolutionary grazing patterns and produce habitat heterogeneity (Toombs et al. 2010, Fuhlendorf et al. 2018); 2) restoring evolutionary grazing processes directly via the reintroduction of bison (Truett et al. 2001, Freese et al. 2014, Fuhlendorf et al. 2018), with the assumption that they will produce heterogeneous grassland landscapes with minimal management beyond containment and population control (Fuhlendorf et al. 2018).

There are several ecological and physiological differences between bison and cattle that support the hypothesis that their divergent grazing patterns will affect biodiversity. Bison are more drought and heat-tolerant, allowing them to graze farther from water, especially during hot conditions (Allred et al. 2013, Kohl et al. 2013). Compared with cattle, bison select against areas with woody vegetation and standing water, spend aine, and specialize more on grasses as opposed to forbs or woody vegetation (Peden et al. 1974, Knapp et al. 1999, Steuter and Hidinger 1999, Allred et al. 2011, Kohl et al. 2013, Ranglack and du Toit 2015).

Given these known differences in foraging behavior, efforts to restore bison to western prairies are increasing in frequency and scale (Freese et al. 2007, Sanderson et al. 2008, U.S. Department of the Interior 2018). Efforts are underway on tribal, federal, and private lands across western North America to reintroduce and manage bison with the ultimate goal of restoring ecological processes that are predicted to enhance habitat quality and heterogeneity (Allred et al. 2011). However, many bison restoration projects are currently small in scale (Sanderson et al. 2008) and, given that bison of the Great Plains historically moved large distances (Chisholm et al. 1986), relatively small pastures sizes may constrain the ability of restored herds to fulfill their ecological function as a keystone species (Lott 2002, Sanderson et al. 2008, Kohl et al. 2013).

There is evidence that restoration of bison at small scales can lead to increased diversity in insects and plants compared with cattle grazing (Moran 2014, McMillan et al. 2018, Nickell et al. 2018), but patterns in birds are equivocal. Combining fire and bison restoration resulted in similar bird communities compared with cattle in one study (Greibel et al. 1998), and reduced densities and diversity in another (Lueders et al. 2006). Bison grazing in a tallgrass prairie system resulted in strong changes to individual species abundance, but overall diversity was not evaluated (Powell 2006). Given the complexities of pasture size, regional ecosystem (tall vs. short vs. mixed-grass prairie), presence or absence of fire, and stocking rate, the question of whether unmanipulated bison or intensively managed cattle produce higher or lower bird diversity is likely to be context-dependent and generally remains an open question.

In addition to grazing management, abiotic factors such as soil composition and precipitation are also drivers of vegetation productivity and diversity which influences bird diversity and abundance. The effect of different grazing regimes on biodiversity can vary in the context of abiotic conditions including precipitation and soil productivity (Lipsey and Naugle 2017). Therefore, large-scale studies that seek to determine the effect of grazing systems on biodiversity must take soil productivity and annual variation into account.

Bison ecology and physiology, which co-evolved with grassland ecosystems for tens of thousands of years, suggests that bison may be well-suited to create heterogeneous grassland landscapes, without the need for intensive management in the form of water and fencing infrastructure typically required for cattle (Truett et al. 2001, Freese et al. 2014), and we aim to test this hypothesis here. We tested whether vegetation heterogeneity and grassland bird diversity differed between pastures grazed year-round by bison with no managed rotation and pastures grazed seasonally by cattle that are rotated through internal fencing. Diversity is an important conservation metric but certain species are especially imperiled and understanding grazing effects on individual species of heightened concern is critical. Furthermore, some imperiled species require large areas with uniform vegetation structure (Somershoe 2018, Pulliam et al. 2020), meaning that community diversity and individual species abundance might often be decoupled. Therefore, in addition to community diversity patterns, we examined if estimated abundances for 11 focal grassland songbirds differed between areas grazed by cattle and bison. Our focal species include but were not limited to Baird's Sparrow (Centronyx bairdii), Sprague's Pipit (Anthus spragueii), and Chestnut-collared Longspur (Calcarius ornatus), all of which have been proposed for listing under the Endangered Species Act in the US and/or Species at Risk Act in Canada (Somershoe 2018).

\section{MATERIALS AND METHODS}

\section{Study system}

We studied grassland bird communities in northcentral Montana within the northwest glaciated plains subregion of the Northern Great Plains ecosystem (Forrest et al. 2004). Our study area included parts of Blaine, Phillips, and Valley counties bounded by the Milk River in the north, the Missouri River in the south, and the western edge of the Fort Belknap Indian Reservation in the west (Fig. 1). This region has the greatest diversity of breeding grassland and sagebrush obligate songbirds in North America (Dreitz et al. 2017). Land ownership is characterized by large blocks of both public and private lands. Land conversion from native grassland to tillage agriculture is rapid on private lands in the region, while remaining private and public rangelands are used for beef production (Gage et al. 2016). 
Table 1. Characteristics of pasture units in our study. Animal unit months (AUMs) used for bison are calculated as (herd size * 1.00 AUE * 12 months). Animal unit equivalent (AUE) value of 1.0 for bison is based on recommendations from Natural Resources Conservation Service (NRCS 2003). AUMs used for cattle are estimated as the permitted number of AUMs according to lease and sublease documents as these are generally equivalent (Rhodes 2020, BLM personal communication). Precise herd size was unavailable for cattle plots so estimates were obtained by dividing permitted AUMs by the number of months (8) in a typical public lands grazing season. Pasture area and herd size data were unavailable for four cattle pastures on the Fort Belknap Indian Reservation.

\begin{tabular}{|c|c|c|c|c|c|c|}
\hline Unit name & Ownership $^{\dagger}$ & $\begin{array}{l}\text { Total allotment area } \\
\text { (ha) }\end{array}$ & $\begin{array}{c}\text { Mean pasture area } \\
\text { (ha) }\end{array}$ & Herd size & AUMs used & AUM $*$ ha $^{-1}$ \\
\hline \multicolumn{7}{|l|}{ Bison } \\
\hline Sun Prairie & APR/BLM/State & 10,909 & 10,909 & 444 & 5,328 & 0.49 \\
\hline Dry Fork & APR & 2,349 & 2,349 & 179 & 2,148 & 0.91 \\
\hline Snake Butte & Ft. Belknap & 8,903 & 8,903 & $\sim 700$ & 8,400 & 0.94 \\
\hline \multicolumn{7}{|l|}{ Cattle } \\
\hline Sun Prairie North & BLM/State & 6,344 & 2,115 & $\sim 226$ & 1,807 & 0.28 \\
\hline Burnt Lodge & APR/BLM/State & 4,198 & 1,050 & $\sim 296$ & 2,371 & 0.56 \\
\hline Timber Creek & APR/BLM/State & 63,924 & 15,981 & $\sim 2,807$ & 22,459 & 0.35 \\
\hline
\end{tabular}

Fig. 1. Map of the study area including the locations of all sampling cells coded by grazer species. The Fort Belknap reservation is shaded in light brown. Management units on both APR and Fort Belknap are outlined in black.

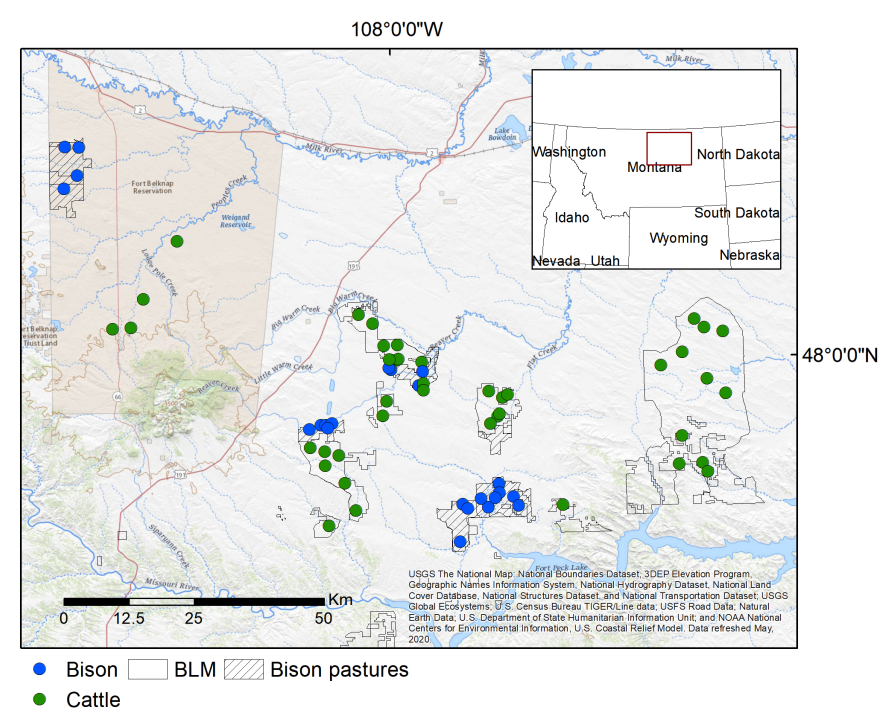

The American Prairie Reserve (APR) is among the largest private landowners in the region with 104,578 acres owned, and 315,047 acres of leased public land as of 2020. A fundamental goal of the reserve is to restore bison to the landscape to fulfill their ecological role as keystone grazers (Knapp et al. 1999, Freese et al. 2018). Currently, APR has restored bison on 3 management units, consisting of 3 private parcels and 2 contiguous public (Bureau of Land Management, BLM) grazing allotments attached to one unit (Table 1). Bison herds are maintained at stocking rates corresponding to normal-year precipitation estimates calculated by BLM staff for public grazing allotments and by a private contractor (EMPSi Inc., Boulder, CO) according to Natural
Resources Conservation Service (NRCS) methodology on private parcels. Bison populations are controlled by public hunting opportunities, donations of animals to other conservation herds, and temporary chemical contraception (Freese et al. 2018). The Fort Belknap Indian Community also maintains a large herd ( 700 individuals) of bison on its Snake Butte pasture. The pasture is approximately 25,000 acres in size and contains approximately 700 bison. This pasture has approximately twice the stocking rate as APR pastures and has been occupied by bison for more than 30 years (B. Speakthunder, FBIR, 2020, personal communication, Table 1).

Cattle pastures within our study area were managed via deferred rotation grazing (B. J. Rhodes 2020, BLM, personal communication). That is, grazing allotments are divided up into 3-4 pastures with interior barbed-wire fence, and cattle are moved sequentially through all pastures over the course of each grazing season (March - November). Bison pastures were managed via continuous grazing, in which bison could move freely within each grazing allotment throughout the year. Cattle pastures have been managed consistently for 10+ years (B. J. Rhodes 2020, BLM, personal communication). Bison pastures have had bison grazing for between 2 and 11 years (Freese et al. 2018). Public lands grazing pressure is relatively consistent over time, with stocking rates set by public lands managers. Bison stocking rates at APR are relatively low compared with cattle stocking rates, while bison stocking rates on the Snake Butte pasture on the Fort Belknap Indian Reservation are approximately double those of APR (Table 1). We did not control for livestock stocking rate in our analyses. Our goal was to compare diversity patterns and estimate species abundance across lands as currently managed, not to control for all management-related variables.

We focused on 12 grassland/sagebrush steppe-specialist passerines for this study (Table 2). We did not include grasslandspecialist shorebirds or raptors because point count survey methods are not well suited to these species. Our focal species span a wide range of habitat preferences, from short grass/bare ground to tall, dense grass, and from sparse to dense shrub cover. 
Table 2. Focal species list of grassland/sagebrush steppe associated songbirds for this study with conservation status, population trends, and generalized habitat associations. Species with an asterisk $\left(^{*}\right)$ are Northern Great Plains breeding endemics. The USFWS designation 'Bird of conservation concern' is abbreviated as BCC.

\begin{tabular}{|c|c|c|c|c|c|}
\hline \multirow[b]{2}{*}{ Common name } & \multirow[b]{2}{*}{ Scientific name } & \multicolumn{3}{|c|}{ Conservation Status ${ }^{*}$} & \multirow[b]{2}{*}{ Habitat association } \\
\hline & & USFWS & BLM & $\begin{array}{l}\text { Population trend } \\
\left(\% \text { year }^{-1}\right)^{\dagger}\end{array}$ & \\
\hline Horned Lark & Eremophila alpestris & & & -2.46 & Bare ground/shortgrass \\
\hline Sprague's Pipit* & Anthus spragueii & $\mathrm{BCC}$ & Sensitive & -3.06 & Dense grass \\
\hline Chestnut-collared Longspur* & Calcarius ornatus & $\mathrm{BCC}$ & Sensitive & -4.18 & Bare ground/shortgrass \\
\hline Thick-billed Longspur* & Rhynchophanes mccownii & $\mathrm{BCC}$ & Sensitive & -4.64 & Bare ground/shortgrass \\
\hline Brewer's Sparrow & Spizella breweri & $\mathrm{BCC}$ & Sensitive & -1.00 & Sagebrush \\
\hline Vesper Sparrow & Pooecetes gramineus & & & -0.86 & Generalist \\
\hline Lark Sparrow & Chondestes grammacus & & & -0.75 & Bare ground \\
\hline Lark Bunting & Calamospiza melanocorys & & & -2.70 & Shrub \\
\hline Savannah Sparrow & Passerculus sandwichensis & & & -1.36 & Generalist/Dense Grass \\
\hline Grasshopper Sparrow & Ammodramus savannarum & $\mathrm{BCC}$ & & -2.46 & Dense grass \\
\hline Baird's Sparrow* & Centronyx bairdii & $\mathrm{BCC}$ & Sensitive & -2.06 & Dense grass \\
\hline Western Meadowlark & Sturnella neglecta & & & -1.30 & Generalist \\
\hline
\end{tabular}

To facilitate site selection, the study area was first gridded into 80 hectare "cells". We then classified vegetation structure for the entire study area using remote-sensed imagery from the National Agriculture Imagery Program (NAIP). We classified vegetation cover by calculating normalized difference vegetation index (NDVI) and used k-means clustering on NDVI values (6 clusters) to assign vegetation structure to one of 6 categories based on NDVI value; water $(<-0.30)$, bare ground $(-0.30--0.08)$, sparse grass $(-0.08-0.02)$, grass $(-0.02-0.10)$, shrub $(0.10-0.29)$, or forest/dense shrub $(>0.29)$. We filtered sites, retaining only those with greater than $85 \%$ bare ground, sparse grass, grass, and shrub combined. Additional sites were later dropped if they were found to have any trees (juniper or cottonwood). We randomly selected cells from the pool, roughly stratified such that equal numbers of cells were selected for bison and cattle portions of APR management units where bison and cattle pastures are adjacent.

\section{Field data}

Songbird abundance

To estimate the abundance of focal songbirds we conducted three 10 -minute $250 \mathrm{~m}$ fixed-radius point counts laid out along either a SW-NE or SE-NW axis within each 80 ha cell such that the center of each point count circle was $500 \mathrm{~m}$ from the nearest count station to prevent double-counting following Hutto et al. (1986). Each cell was visited once per field season between May 13 and June 5, in 2018 and in 2019. All birds seen or heard were recorded, along with distance and bearing. Bearing to each individual bird was recorded only to help prevent double-counting. Point counts were started no earlier than 30 minutes before sunrise and no later than 8:00 am to minimize variation in detectability related to time of day. Following Hutto et al. (1986), point counts were not conducted during strong wind or precipitation.

\section{Vegetation communities}

We used ocular estimation of ground cover and shrub cover to characterize vegetation communities at our sampling sites. Each cell contained 3 point-count locations and we sampled 3 vegetation plots for each point-count location, for a total of 9 vegetation plots per cell. Vegetation plots were located on the center point for each point count location as well as $100 \mathrm{~m}$ north and south of those points. Vegetation was sampled within a 5-m radius of each plot center point. Technicians used a 5-m string attached to a heavy object placed at the center point and walked the circumference of the vegetation plot before estimation. For each plot, percent groundcover was estimated for bare ground, lichen/moss, rock, native grass, non-native grass, forbs, and woody stems. Percent shrub cover was estimated from above for sagebrush (Artemesia tridentata) and all other woody shrubs combined. Average height was estimated for native and nonnative grass, forbs, sagebrush, and other woody shrubs.

\section{Statistical analyses}

\section{Estimating Abundance}

We used distance sampling to estimate density and abundance of each species within each 80-hectare cell (Buckland et al. 1993). Given 3 non-overlapping point count circles of $250 \mathrm{~m}$ radius, we assumed 58.8 surveyed hectares to be representative of bird communities within an 80 hectare cell. To estimate detection functions for each species we fit models using half-normal and hazard rate key functions, and all combinations of observer and ordinal date to account for variation in detection probability due to differences among technicians and across the breeding season. Final models were chosen based on model fit (AIC) such that the simplest model with $<4 \Delta \mathrm{AIC}_{\mathrm{c}}$ was chosen. We used the three point-count stations within each block to estimate detection probability. Analyses were done using the 'Distance' package (Miller et al. 2019). This and all following analyses were done in R v. 3.5.1 "Feather Spray" (R Core Team 2015).

\section{Community Diversity}

We used species richness and Shannon's diversity index as indices of community diversity for each sampling cell. Species richness estimates are a fundamental and simple metric of community diversity. However, estimates of species richness can be biased and inaccurate when effort or detectability of species are heterogeneous with respect to sampling effort (Boulinier et al. 
1998). To alleviate potential bias, we calculated Chao's species richness estimator, 'Chao1', for each sampling cell using the package 'SpadeR'(Chao and Chiu 2016). For our data, these estimates were identical to raw species richness estimates, potentially due to the generally high and invariable detectability of grassland birds during the breeding season (Lipsey and Naugle 2017) and the limited pool of focal species. Accordingly, species richness was simply defined as the number of species present within a given cell for community diversity analyses. We chose Shannon's diversity index as a secondary metric of community diversity because it increases with both raw species richness and species evenness and rewards the presence of rare species (Pielou 1966), which are generally those of highest conservation concern in our system. We compiled estimated abundances for all bird species for each cell. Shannon's diversity index was calculated using the 'diversity' function in the package 'vegan' (Oksanen et al. 2019).

We then used linear mixed-effects models to test whether the two metrics of diversity differed among grazing treatments. We determined the best models of diversity by including grazer and several grazer-independent variables known to affect habitat selection of grassland birds. We used remotely-sensed data to estimate slope, terrain roughness, shrub cover, and range productivity for each cell. We extracted shrub cover percentage using the National Land Cover Dataset (Xian et al. 2015, Yang et al. 2018). Estimates of average slope and terrain roughness were extracted from the Nation Elevation Dataset provided by U.S. Geological Survey (Gesch et al. 2002). Average rangeland productivity for each sampling cell was extracted from the NRCS Web Soil Survey (NRCS 2003). Rangeland productivity is a composite metric that includes soil, rainfall, and topographical information to estimate the annual potential production of forage given average annual precipitation. We included a quadratic term for shrub cover and a binary variable for year. All of the above were included as fixed effects. Because not all cells were sampled in each year, we included cell as a random effect. We used the 'dredge' function in the 'MuMin' package (Barton 2019) to fit all possible models and assessed model fit using AIC (Burnham and Anderson 2002). We assessed all models with $\Delta \mathrm{AIC}_{\mathrm{c}}<2$ but removed models with uninformative parameters per Arnold (2010).

\section{Ordination}

We used non-metric multidimensional scaling (NMDS) using Bray-Curtis dissimilarity matrices to visualize variation in directly sampled local-scale bird and vegetation communities within and among sites across the two grazing treatments (Kruskal 1964). Because NMDS algorithms can converge on local optima, we conducted a minimum of 40 random starts to identify an optimum solution. Solutions were then evaluated for fit based on their stress values according to Clarke (1993), such that stress values below 0.2 provide a useful representation of the data, and goodness of fit improving as values approach 0 . After solutions were identified, we used "envfit" to identify which species were correlated with our two NMDS axes, as well as the directionality and strength of these associations. Significance of these correlations was assessed using 999 permutations and correlations are only presented for species where $\mathrm{p}<0.05$. All ordination analyses were performed using the 'vegan' package (Oksanen et al. 2019).

\section{Species-specific responses to grazing}

We fit generalized linear models to describe the relationships between estimated abundance and grazer, controlling for grazingindependent covariates, for 11 of 12 focal species. We had too few detections of Thick-billed Longspur to model responses to grazing treatment for this species. This suite of species includes three of highest conservation concern in the region- Baird's Sparrow, Sprague's Pipit, and Chestnut-collared Longspur-but most species within this group are experiencing significant negative trends (Sauer et al. 2017, Somershoe 2018; Table 2). Our focal group also includes Brewer's Sparrow, a sagebrush obligate songbird of high conservation interest across the western US. Taken together, this group of species encompasses a broad range of vegetation structure preferences and is the most diverse grassland songbird assemblage studied in the context of bison restoration (Knopf 1996, Somershoe 2018). Due to the known over-dispersion of avian count data (White and Bennetts 1996), we used negative binomial generalized linear models to assess whether density of species of concern differed between grazing treatments after accounting for other factors known to be highly influential on grassland bird occupancy and abundance; topography, soil productivity and shrub cover (Lipsey and Naugle 2017, Somershoe 2018, Pulliam et al. 2020). Abundance estimates from distance sampling (see above) were rounded to the nearest integer for model fitting. For these analyses, we included fixed effects of grazer, slope, terrain roughness, normal year range productivity (NRCS 2003), and year, as well as linear and quadratic terms for woody shrub cover. We chose to include shrub cover because it is highly variable across our study area, is known to strongly influence occupancy of grassland songbirds (Somershoe 2018), and is not strongly influenced by low or moderate-intensity grazing over short periods of time (Holechek and Stephenson 1983).

\section{RESULTS}

We conducted 279 point-counts within a total of 64 survey cells during 2018 and 2019, 23 in bison pastures and 41 in cattle pastures (Fig. 1). We detected all 12 focal grassland songbird species and all species were detected in both bison and cattle plots. Grassland bird community diversity was similar between cattle and bison plots after accounting for effects of grazingindependent variables (Table 3, Fig. 2). This pattern was consistent using both species richness and Shannon's index as metrics of community diversity (Table 3). Among grazingindependent variables, slope had a negative effect on species richness $(\beta=-0.21 ; p=0.02)$ but the null model best explained variation in Shannon's diversity (Table 3).

NMDS ordination procedures arrived at two-dimensional solutions for both avian and vegetative communities. Stress values of 0.19 and 0.18 , respectively, indicate ordination plots adequately represent similarity relationships among avian and vegetative data, respectively (Clarke 1993). Ordination plots show broad overlap in vegetative communities between the two treatments, but cattle plots encompassed a broader range of vegetative and bird communities, particularly those with higher percentages of bare ground and rock, with associated bird species, Horned Lark and Lark Bunting (Fig. 3). 
Table 3. Model selection table for the effects of grazer and local scale (80 ha) grazing-independent site attributes on grassland songbird diversity. All variables were included as fixed-effects and a random effect of cell ID was included in all models. Only models with $\triangle \mathrm{AICc}<2$ and the null model are listed for each metric. Competitive models with uninformative parameters (Arnold 2010) were removed.

\begin{tabular}{lcccc}
\hline \hline Model & $\mathrm{AIC}_{\varsigma}$ & $\Delta \mathrm{AIC}$ & $w_{i}$ & $\sum w_{i}$ \\
\hline Species richness & & & & \\
$\quad$ slope + (1|cell) & 311.5 & 0.00 & 0.26 & 0.26 \\
$\quad(1 \mid$ cell) & 312.1 & 0.64 & 0.19 & 0.45 \\
$\begin{array}{l}\text { Shannon's diversity index } \\
\quad(1 \mid \text { cell) }\end{array}$ & 29.0 & 0.00 & 0.39 & 0.39 \\
\hline
\end{tabular}

Fig. 2. Comparisons of grassland bird community diversity, quantified as species richness and Shannon's diversity index, across two grazing management regimes. Bison are grazed yearround with free movement within management units, while cattle are grazed seasonally and are rotated among pastures within management units.
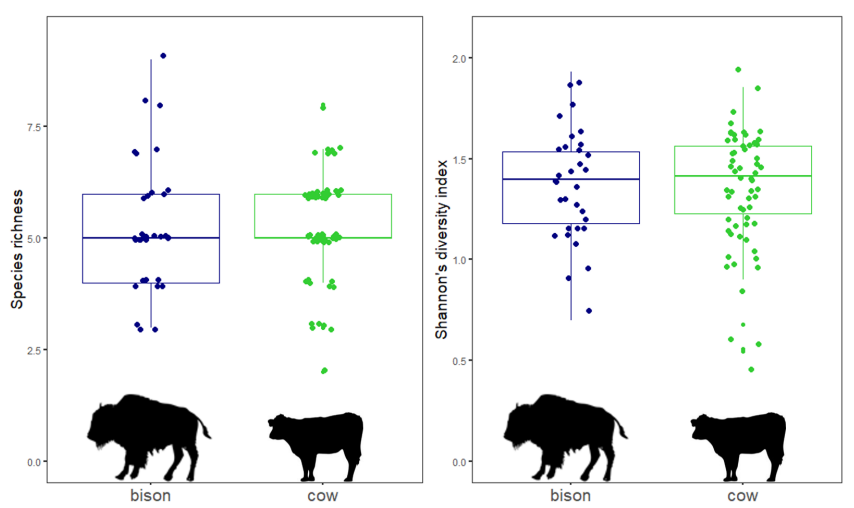

Abundances of songbird species were broadly similar between bison and cattle cells after accounting for variation in grazingindependent variables. There was no significant effect of grazer species on 9 of 11 focal species but estimated abundances of vesper sparrow and grasshopper sparrow were higher on bison pastures (Table 4, Fig. 4). Chestnut-collared Longspur and Lark Sparrow showed trends towards higher abundance on cattle plots (Fig. 4), but these trends were not significant (Table 4), potentially due to large variation in abundance across sites in the case of the longspur, and an overall paucity of detections in the case of Lark Sparrow. The influence of grazer-independent covariates on the three northern great plains breeding endemic species-Baird's Sparrow, Chestnut-collared Longspur, and Sprague's Pipitshared some similarities but also with distinct differences (Table 4). All three species showed declining abundance with increasing slope and decreasing terrain roughness. Both Baird's Sparrow and Sprague's Pipit showed increasing abundance with higher rangeland productivity values. Abundance of Baird's Sparrows declined at sites with high shrub cover, while Sprague's Pipit abundance peaked at sites with intermediate shrub cover values and Chestnut-collared Longspur abundance was highest at sites with the high and low shrub cover percentages but declined with increasing shrub cover overall (Table 4 ). While our results generally agree with known habitat associations of these species (reviewed in Somershoe 2018), our study design only allows for inference at the local scale and does not examine relationships between detailed characteristics of vegetation structure and species abundance. Recent work focusing specifically on these relationships should be used to inform vegetation management and assessment of priority conservation areas for individual species (e.g., Lipsey \& Naugle 2017; Somershoe 2018; Pulliam et al. 2020).

Fig. 3. Top: NMDS ordination plots showing the distribution of avian and vegetation communities across three grazing management regimes. Bottom: Correlations between grassland bird species, vegetation communities and NMDS ordination axes. Only bird species and vegetation components with significant correlations are shown. Vector length is proportional to correlation strength.
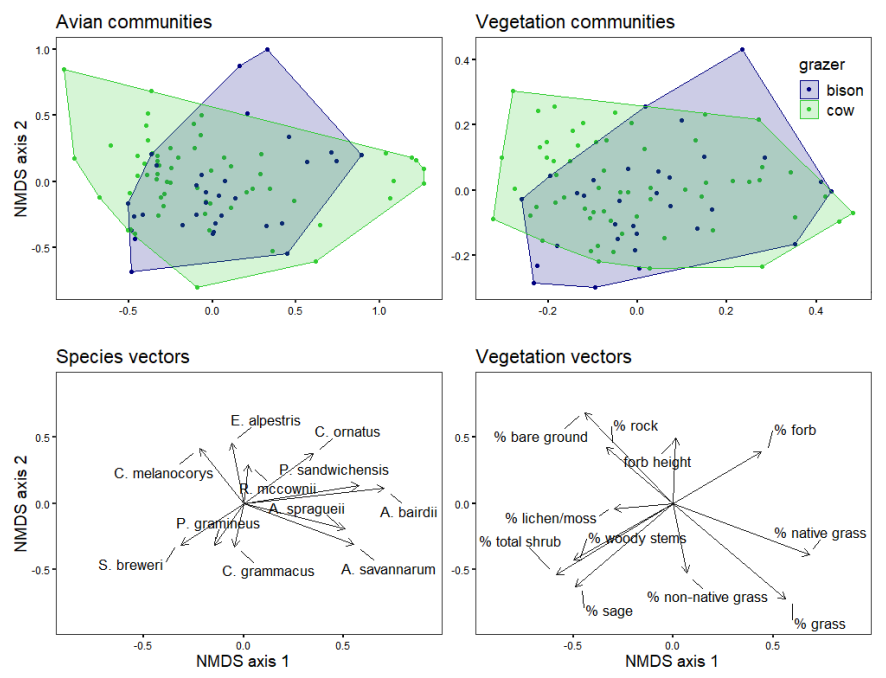

Fig. 4. Parameter estimates and associated standard errors for songbird estimated abundance as a function of grazer, controlling for grazer-independent variables (Table 4).

Coefficient values are for cattle in comparison to bison, thus, positive values mean higher abundances in the presence of cattle.

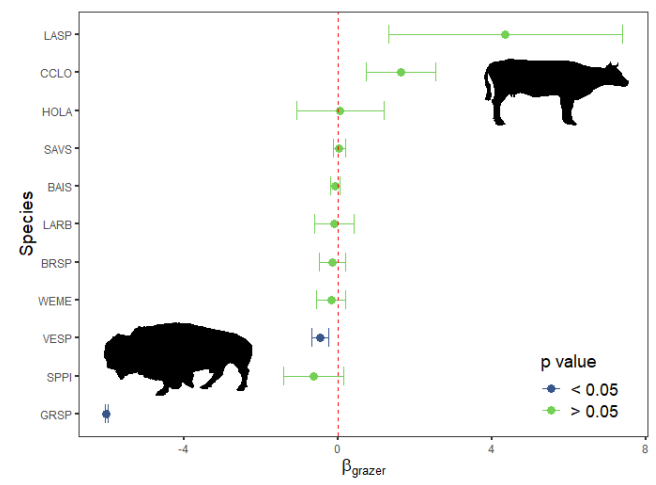


Table 4. Parameter estimates and associated standard errors for grazer and grazing-independent site attributes on estimated abundance of grassland songbirds in our study area. Grazer effects are in comparison to bison. Effect sizes are only reported for variables where $\mathrm{p}<0.05$.

\begin{tabular}{|c|c|c|c|c|c|c|c|}
\hline & grazer (cattle) & $\begin{array}{l}\text { range prod. } \\
\left(\mathrm{lbs} / \mathrm{ha}^{-\mathrm{yr}}\right)\end{array}$ & $\begin{array}{c}\% \text { shrub cover } \\
\text { (80 ha) }\end{array}$ & $\begin{array}{c}\% \text { shrub cover }{ }^{2} \\
(80 \text { ha })\end{array}$ & slope & terrain roughness & year (2019) \\
\hline Horned Lark & - & $-0.002 \pm<0.001$ & $-0.14 \pm 0.05$ & $0.002 \pm<0.001$ & & & $0.68 \pm 0.33$ \\
\hline Sprague's Pipit & - & $0.005 \pm 0.002$ & $0.30 \pm 0.13$ & $-0.006 \pm 0.002$ & $-1.15 \pm 0.41$ & $0.72 \pm 0.16$ & $2.03 \pm 0.82$ \\
\hline $\begin{array}{l}\text { Chestnut-collared } \\
\text { Longspur }\end{array}$ & - & - & $-0.57 \pm 0.13$ & $0.007 \pm 0.002$ & $-1.49 \pm 0.37$ & $0.37 \pm 0.16$ & - \\
\hline Brewer's Sparrow & - & $-0.005 \pm<0.001$ & - & - & - & - & - \\
\hline Vesper Sparrow & $-0.46 \pm 0.002$ & $-0.21 \pm<0.029$ & & & & $0.12 \pm 0.04$ & $0.86 \pm 0.20$ \\
\hline Lark Sparrow & - & - & - & - & $4.52 \pm 1.30$ & - & $-6.00 \pm 2.25$ \\
\hline Lark Bunting & - & $-0.006 \pm 0.002$ & $-0.14 \pm 0.07$ & $0.002 \pm<0.001$ & $-0.57 \pm 0.20$ & $-0.28 \pm 0.12$ & $-1.61 \pm 0.48$ \\
\hline Savannah & - & $0.003 \pm<0.001$ & $0.08 \pm 0.02$ & $-0.002 \pm<0.001$ & $-0.61 \pm 0.09$ & $-0.15 \pm 0.05$ & $1.49 \pm 0.19$ \\
\hline Sparrow & & & & & & & \\
\hline $\begin{array}{l}\text { Grasshopper } \\
\text { Sparrow }\end{array}$ & $-6.01 \pm 0.038$ & $0.002 \pm<0.001$ & $0.09 \pm<0.01$ & $-0.002 \pm<0.001$ & $0.09 \pm<0.01$ & $0.11 \pm<0.01$ & - \\
\hline Baird's Sparrow & - & $0.004 \pm<0.001$ & $-0.04 \pm 0.02$ & - & $-0.35 \pm 0.07$ & $0.08 \pm 0.02$ & $1.28 \pm 0.17$ \\
\hline $\begin{array}{l}\text { Western } \\
\text { Meadowlark }\end{array}$ & - & $-0.001 \pm<0.001$ & $0.04 \pm 0.02$ & $-0.001 \pm<0.001$ & - & $0.05 \pm 0.02$ & $0.29 \pm 0.11$ \\
\hline
\end{tabular}

\section{DISCUSSION}

Our results show that year-round bison grazing and rotational cattle grazing accommodate similarly diverse grassland bird communities and support similar abundances of most grassland songbird species, including those of highest conservation concern. We found higher numbers of Grasshopper Sparrow and Vesper Sparrow in bison pastures, suggesting a potential benefit of bison restoration for these species. Our results fit well with other studies that found grazing systems to be of secondary importance for grassland bird diversity compared with other variables including stocking rate, soil composition, precipitation, topography, and woody vegetation (Briske et al. 2011, Lipsey and Naugle 2017, Vold et al. 2019) and extends this pattern to include little support for differences between the two species. Furthermore, our work provides support for the longstanding idea that large bovine grazers can coexist with and produce habitat for a diverse grassland bird community and we find no evidence of negative effects of either deferred rotation cattle grazing or year-round bison grazing on upland birds on the Northern Great Plains (Milchunas et al. 1998, Eby et al. 2014).

Previous studies of grassland bird responses to bison grazing have differed from our study in two important ways. First, comparative studies have often paired bison and fire treatments, to test the effects of an evolutionary disturbance regime on grassland bird communities (Lueders et al. 2006, Williams and Boyle 2018). While restoring fire to grassland ecosystems can enhance heterogeneity and restore a key ecological process, social inertia within ranching communities continues to prevent its use across much of the Great Plains (Sliwinski et al. 2018). This reality necessitates an understanding of the biodiversity effects of yearround bison grazing in the absence of fire. Second, studies of bison effects on bird communities have often been restricted to a small subset of grassland obligate species or occurred outside the range of several species of greatest conservation concern (Greibel et al. 1998, Williams and Boyle 2018). Given the critical need to arrest declines of several Northern Great Plains breeding endemic songbirds (Somershoe 2018), our study highlights the ability of bison grazing to provide high quality habitat for these species, even in the absence of fire.

APR pastures have contained bison for only 2-12 years, following decades of grazing by cattle or sheep. Thus, there are probably long-term effects of replacing cattle with bison that remain undetected in this study. For example, the cumulative rubbing of bison on woody vegetation over prolonged periods has the potential to slow or arrest woody plant encroachment onto grasslands (Coppedge and Shaw 1997, Oquiñena Valluerca 2009). This possibility deserves further study, as woody plant encroachment is driving the loss or degradation of grassland habitat worldwide (Naito and Cairns 2011). Due to selection against riparian areas, bison also likely have a reduced impact on riparian vegetation compared with cattle. Intact riparian habitats provide myriad benefits to both terrestrial and aquatic biodiversity in grassland ecosystems (Dosskey 1998, Limb et al. 2009). Furthermore, APR bison are managed in the absence of interior fencing for pasture rotation, thus reducing the deleterious impacts of fencing on movement and mortality of other wildlife such as pronghorn (reviewed in Gates et al. 2012) or Sage Grouse (Stevens et al. 2012). In fact, wildlife-friendly electric fencing used by APR to contain bison is more permeable to ungulate movements than normal 4-wire barbed-wire fencing typical of cattle pastures (Segar and Keane 2020), so fencing of bison pastures provides additive benefits of dramatically lower fence mileage per unit area and increased fence permeability for ungulates. This management strategy is not cost-free however, as significant investment is necessary for construction and maintenance of perimeter fences. It should also be noted that similar wildlife-friendly fencing can be used to contain cattle, so it is not a feature necessarily associated with bison. Because the absence of interior cross-fencing and continuous year-round grazing show no negative effects on grassland bird diversity and provide ecosystem benefits of fence removal, our results support the continued use of this grazing system for bison in the Northern Great Plains region. 
Pasture size and stocking rates are both known to mediate effects of grazers on grassland bird communities (Sliwinski and Koper 2015, Lipsey and Naugle 2017, Vold et al. 2019). Little is known about these relationships in the context of bison due to limited sample size of management units and the distribution of herds across multiple ecosystems. We propose that free-ranging bison grazing at large scales (thousands of bison over hundreds of thousands of acres) may yield significantly different results. Optimum stocking rates for bird communities are certain to vary with rangeland productivity (Lipsey and Naugle 2017) such that inference from one site may not be directly applicable elsewhere.

Several important data gaps remain regarding the impact of native grazers on grassland bird communities. First, occupancy and/or density are not perfect proxies for demographic rates. More work is needed to understand how critical vital rates including nest predation, nest parasitism, and adult and juvenile survival vary in the presence of native versus non-native grazers. Importantly, we need to know what the habitat potential is for these grasslands for imperiled bird productivity and if we are maximizing it, given the critical status of these species. Second, raptors, shorebirds, and riparian-associated birds that rely on grassland ecosystems are difficult to survey via standard methods but are important members of grassland bird communities, and some of these species are also in rapid decline (e.g., Mountain Plover, Sauer et al. 2017, Rosenberg et al. 2019).

Year-round grazing of bison at stocking rates similar to (APR) and above (Fort Belknap) standard cattle stocking rates did not cause degradation of grassland bird communities and did yield high quality habitat for grassland birds without rotation among pastures. In areas where intensive management of cattle is impractical due to lack of fencing or water infrastructure, where cattle are known to cause environmental degradation (reviewed in Fleischner 1994), or where land management legislation prioritizes native species, bison are a low-infrastructure alternative capable of supporting diverse grassland bird communities which include many species of high conservation concern.

Responses to this article can be read online at: https://www.ace-eco.org/issues/responses.php/1944

\section{Author Contributions:}

AJB, KEK \& WJM conceived of the idea and study design. AJB and HS collected the data and performed the analyses. AJB wrote the paper and all authors contributed to revisions.

\section{Acknowledgments:}

Thank you to 2 anonymous reviewers for comments that improved the manuscript. We thank the people of the Assiniboine (Nakoda) and Gros Ventre (Aaniiih) Tribes for giving us access to their homes. We would also like to thank Curt Freese, Daniel Kinka, and Damien Austin at the American Prairie Reserve, B.J. Rhodes with the BLM Malta Field Office, Harold Main from Fort Belknap Fish \& Wildlife Department, and Randy Matching at the Charles M. Russell NWR for assistance with fieldwork and planning. AJB would also like to thank Amy Seaman, Lars Anderson, Scott Heidebrink, and many tremendous interns for invaluable assistance in the field. This work was made possible by the generous support of John and Adrienne Mars. All work was conducted under the auspices of the Smithsonian Conservation Biology Institute ACUC Committee.

\section{LITERATURE CITED}

Allred, B. W., S. D. Fuhlendorf, and R. G. Hamilton. 2011. The role of herbivores in Great Plains conservation: Comparative ecology of bison and cattle. Ecosphere 2:1-17. https://doi. org/10.1890/ES10-00152.1

Allred, B. W., S. D. Fuhlendorf, T. J. Hovick, R. D. Elmore, D. M. Engle, and A. Joern. 2013. Conservation implications of native and introduced ungulates in a changing climate. Global Change Biology 19:1875-1883. https://doi.org/10.1111/gcb.12183

Arnold, T. W. 2010. Uninformative parameters and model selection using Akaike's information criterion. Journal of Wildlife Management 74:1175-1178. https://doi.org/10.1111/j.1937-2817.2010. tb01236.x

Barton, K. 2020. MuMIn: Multi-Model Inference. R package version 1.43.17. https://CRAN.R-project.org/package=MuMIn

Boulinier, T., J. D. Nichols, J. R. Sauer, J. E. Hines, and K. H. Pollock. 1998. Estimating species richness: the importance of heterogeneity in species detectability. Ecology 79:1018-1028. https://doi.org/10.1890/0012-9658(1998)079[1018:ESRTIO]2.0.CO;2

Briske, D. D., J. D. Derner, , D. G.Milchunas, and K. Tate. 2011. An evidence-based assessment of prescribed grazing practices. Book Chapter. In: D.D. Briske, editor. Conservation Benefits of Rangeland Practices: Assessment, Recommendations, and Knowledge Gaps. United States Department of Agriculture, Natural Resources Research Service. pp. 21-74.

Buckland, S. T., D. R. Anderson, K. P. Burnham, and J. L. Laake. 1993. Distance sampling: estimating abundance of biological populations. Chapman \& Hall, London.

Burnham, K. P., and D. Anderson. 2002. Model selection and multimodal inference: a practical information-theoretic approach. Springer-Verlag, New York, NY.

Chao, A., and C.-H. Chiu. 2016. Species richness: estimation and comparison. Wiley StatsRef: Statistics Reference Online 1:1-26. https://doi.org/10.1002/9781118445112.stat03432.pub2

Chisholm, B., J. Driver, S. Dube, and H. P. Schwarcz. 1986. Assessment of prehistoric bison foraging and movement patterns via stable-carbon isotope analysis. Plains Anthropologist 31:193-205. https://doi.org/10.1080/2052546.1986.11909302

Clarke, K. R. 1993. Non-parametric multivariate analyses of changes in community structure. Australian Journal of Ecology 18:117-143. https://doi.org/10.1111/j.1442-9993.1993.tb00438.x

Coppedge, B. R., and J. H. Shaw. 1997. Effects of horning and rubbing behavior by bison (Bison bison) on woody vegetation in a tallgrass prairie. The American Midland Naturalist 138:189-196. https://doi.org/10.2307/2426665 
Dosskey, M. G. 1998. Viewpoint: applying riparian buffers to Great Plains. Journal of Range Management 51:428-431. https:// doi.org/10.2307/4003328

Dreitz, V. J., L. T. Stinson, B. A. Hahn, J. D. Tack, and P. M. Lukacs. 2017. A large-scale perspective for managing prairie avifauna assemblages across the western US: influences of habitat, land ownership and latitude. PeerJ 5:e2879. https://doi. org/10.7717/peerj.2879

Eby, S., D. E. Burkepile, R. W. S. Fynn, C. E. Burns, N. Govender, N. Hagenah, S. E. Koerner, K. J. Matchett, D. I. Thompson, K. R. Wilcox, S. L. Collins, K. P. Kirkman, A. K. Knapp, and M. D. Smith. 2014. Loss of a large grazer impacts savanna grassland plant communities similarly in North America and South Africa. Oecologia 175:293-303. https://doi.org/10.1007/s00442-014-2895-9

Fleischner, T. L. 1994. Ecological costs of livestock grazing in Western North America. Conservation Biology 8:629-644. https://doi.org/10.1046/j.1523-1739.1994.08030629.x

Forrest, S., H. Strand, W. H. Haskins, C. Freese, J. Proctor, and E. Dinerstein. 2004. Ocean of Grass: A Conservation Assessment for the Northern Great Plains. Northern Plains Conservation Network and Northern Great Plains Ecoregion, WWF-US, Bozeman, MT.

Freese, C. H., K. E. Aune, D. P. Boyd, J. N. Derr, S. C. Forrest, C. Cormack Gates, P. J. P. Gogan, S. M. Grassel, N. D. Halbert, K. Kunkel, and K. H. Redford. 2007. Second chance for the plains bison. Biological Conservation 136:175-184. https://doi. org/10.1016/j.biocon.2006.11.019

Freese, C. H., S. D. Fuhlendorf, and K. Kunkel. 2014. A management framework for the transition from livestock production toward biodiversity conservation on great plains rangelands. Ecological Restoration 32:358-368. https://doi. org/10.3368/er.32.4.358

Freese, C. H., K. E. Kunkel, D. Austin, and B. Holder. 2018. Bison Management Plan. American Prairie Reserve, Bozeman, MT.

Fuhlendorf, S. D., C. A. Davis, R. D. Elmore, L. E. Goodman, and R. G. Hamilton. 2018. Perspectives on grassland conservation efforts: Should we rewild to the past or conserve for the future? Philosophical Transactions of the Royal Society B: Biological Sciences 373 .

Fuhlendorf, S. D., D. M. Engle, R. D. Elmore, R. F. Limb, and T. G. Bidwell. 2012. Conservation of pattern and process: developing an alternative paradigm of rangeland management. Rangeland Ecology and Management 65:579-589. https://doi. org/10.2111/REM-D-11-00109.1

Gage, A. M., S. K. Olimb, and J. Nelson. 2016. Plowprint: tracking cumulative cropland expansion to target grassland conservation. Great Plains Research 26:107-116. https://doi.org/10.1353/ gpr.2016.0019

Gates, C. C., P. Jones, M. Suitor, A. F. Jakes, M. S. Boyce, K. E. Kunkel, and K. Wilson. 2012. The influence of land use and fences on habitat effectiveness, movements and distribution of pronghorn in the grasslands of North America. Pages 1-320 in M. J. Somers and M. W. Hayward, editors. Fencing for
Conservation: Restriction of Evolutionary Potential Or a Riposte to Threatening Processes? Springer, New York. https://doi. org/10.1007/978-1-4614-0902-1_15

Gesch, D., M. Oimoen, S. Greenlee, C. Nelson, M. Steuck, and D. Tyler. 2002. The national elevation dataset. Photogrammetric Engineering and Remote Sensing 68:5-11.

Greibel, R. L., S. L. Winter, and A. A. Steuter. 1998. Grassland birds and habitat structure in sandhills prairie managed using cattle or bison plus fire. Great Plains Research 8:255-268.

Henwood, W. D. 2010. Toward a strategy for the conservation of the world's temperate grasslands. Great Plains Research 20:121-134.

Hoekstra, J. M., T. M. Boucher, T. H. Ricketts, and C. Roberts. 2005. Confronting a biome crisis: global disparities of habitat loss and protection. Ecology Letters 8:23-29. https://doi.org/10.1111/ j.1461-0248.2004.00686.X

Holechek, J. L., and T. Stephenson. 1983. Comparison of big sagebrush vegetation in northcentral New Mexico under moderately grazed and grazing excluded conditions. Journal of Range Management 36:455-456. https://doi.org/10.2307/3897939

Hutto, R. L., S. M. Pletschet, and P. Hendricks. 1986. A fixedradius point count method for nonbreeding and breeding season use. The Auk 103:593-602. https://doi.org/10.1093/auk/103.3.593

Knapp, A. K., J. M. Blair, J. M. Briggs, S. L. Collins, D. C. Hartnett, L. C. Johnson, and E. G. Towne. 1999. The keystone role of bison in North American tallgrass prairie. BioScience 49:39-50. https://doi.org/10.2307/1313492

Knopf, F. L. 1994. Avian assemblages on altered grasslands. Studies in Avian Biology 15:247-257.

Knopf, F. L. 1996. Prairie Legacies -- Birds. Pages 135-148 Prairie Conservation. Island Press, Washington, DC.

Kohl, M. T., P. R. Krausman, K. Kunkel, and D. M. Williams. 2013. Bison versus cattle: Are they ecologically synonymous. Rangeland Ecology and Management 66:721-731. https://doi. org/10.2111/REM-D-12-00113.1

Kruskal, J. B. 1964. Multidimensional scaling by optimizing goodness of fit to a nonmetric hypothesis. Psychometrika 29:1-27. https://doi.org/10.1007/BF02289565

Limb, R. F., S. D. Fuhlendorf, and D. E. Townsend. 2009. Heterogeneity of thermal extremes: driven by disturbance or inherent in the landscape. Environmental Management 43:100-106. https://doi.org/10.1007/s00267-008-9147-x

Lipsey, M. K., and D. E. Naugle. 2017. Precipitation and soil productivity explain effects of grazing on grassland songbirds. Rangeland Ecology and Management 70:331-340. https://doi. org/10.1016/j.rama.2016.10.010

Lott, D. F. 2002. American bison: a natural history. University of California Press, Los Angeles, CA.

Lueders, A. S., P. L. Kennedy, and D. H. Johnson. 2006. Influences of management regimes on breeding bird densities and habitat in 
mixed-grass prairie: an example from North Dakota. Journal of Wildlife Management 70:600-606. https://doi.org/10.2193/0022-541X (2006)70[600:IOMROB]2.0.CO;2

Manning, R. 1995. Grassland: The history, biology, politics and promise of the American prairie. Penguin Books, New York, NY.

McMillan, N. A., K. E. Kunkel, D. L. Hagan, and D. S. Jachowski. 2018. Plant community responses to bison reintroduction on the Northern Great Plains, United States: a test of the keystone species concept. Restoration Ecology: 27(2):379-388. https://doi. org/10.1111/rec.12856

Milchunas, D. G., W. K. Lauenroth, and I. C. Burke. 1998. Livestock grazing: animal and plant biodiversity of shortgrass steppe and the relationship to ecosystem function. Oikos 83:65-74. https://doi.org/10.2307/3546547

Miller, D. L., E. Rexstad, L. Thomas, L. Marshall, and J. L. Laake. 2019. Distance sampling in R. Journal of Statistical Software 89:1-28. https://doi.org/10.18637/jss.v089.i01

Moran, M. D. 2014. Bison grazing increases arthropod abundance and diversity in a tallgrass prairie. Environmental Entomology 43:1174-1184. https://doi.org/10.1603/EN14013

Naito, A. T., and D. M. Cairns. 2011. Patterns and processes of global shrub expansion. Progress in Physical Geography 35:423-442. https://doi.org/10.1177/0309133311403538

Natural Resources Conservation Service (NRCS). 2003. National Range and Pasture Handbook. Revision 1. U.S. Department of Agriculture, Natural Resources Conservation Service, Grazing Lands Technology Institute. Washington, DC, USA.

Nickell, Z., S. Varriano, E. Plemmons, and M. D. Moran. 2018. Ecosystem engineering by bison (Bison bison) wallowing increases arthropod community heterogeneity in space and time. Ecosphere 9. https://doi.org/10.1002/ecs2.2436

Oksanen, J., F. G. Blanchet, M. Friendly, R. Kindt, P. Legendre, D. McGlinn, P. R. Minchin, R. B. O'Hara, G. L. Simpson, P. Solymos, M. Henry, H. Stevens, E. Szoecs and H. Wagner. 2020. vegan: Community Ecology Package. $\mathrm{R}$ package version 2.5-7. https://CRAN.R-project.org/package=vegan

Oquiñena Valluerca, I. 2009. Analysis of vegetation changes induced by a European bison herd in the Kraansvlak area (2003-2009). Utrecht University, Netherlands.

Peden, D. G., G. M. Van Dyne, R. W. Rice, and R. M. Hansen. 1974. The trophic ecology of Bison bison L. on shortgrass plains. Journal of Applied Ecology 11:489-497. https://doi.org/10.2307/2402203

Pielou, E. C. 1966. Shannon's formula as a measure of specific diversity: its use and misuse. The American Naturalist 100:463-465. https://doi.org/10.1086/282439

Powell, A. F. L. A. 2006. Effects of prescribed burns and bison (Bos bison) grazing on breeding bird abundances in tallgrass prairie. The Auk 123:183-197. https://doi.org/10.1093/auk/123.1.183

Pulliam, J. P., S. Somershoe, M. Sather, and L. B. McNew. 2020. Habitat targets for imperiled grassland birds in northern mixedgrass prairie. Rangeland Ecology and Management. https://doi. org/10.1016/j.rama.2020.02.006
R Core Team. 2015. R: A language and environment for statistical computing. R Foundation for Statistical Computing, Vienna, Austria.

Ranglack, D., and J. T. du Toit. 2015. Habitat selection by freeranging bison in a mixed grazing system on public land. Rangeland Ecology and Management 68:349-353. https://doi. org/10.1016/j.rama.2015.05.008

Rosenberg, K. V., A. M. Dokter, P. J. Blancher, J. R. Sauer, A. C. Smith, P. A. Smith, J. C. Stanton, A. Panjabi, L. Helft, M. Parr, and P. P. Marra. 2019. Decline of the North American avifauna. Science 366:120-124. https://doi.org/10.1126/science.aaw1313

Sanderson, E. W., K. H. Redford, B. Weber, K. Aune, D. Baldes, J. Berger, D. Carter, C. Curtin, J. Derr, S. Dobrott, E. Fearn, C. Fleener, S. Forrest, C. Gerlach, C. Cormack Gates, J. E. Gross, P. Gogan, S. Grassel, J. A. Hilty, M. Jensen, K. Kunkel, D. Lammers, R. List, K. Minkowski, T. Olson, C. Pague, P. B. Robertson, and B. Stephenson. 2008. The ecological future of the North American bison: conceiving long-term, large-scale conservation of wildlife. Conservation Biology 22:252-266. https://doi. org/10.1111/j.1523-1739.2008.00899.x

Sauer, J. R., K. L. Pardieck, D. J. Ziolkowski, A. C. Smith, M.A. R. Hudson, V. Rodriguez, H. Berlanga, D. K. Niven, and W. A. Link. 2017. The first 50 years of the North American Breeding Bird Survey. The Condor 119:576-593. https://doi.org/10.1650/ CONDOR-17-83.1

Segar, J., and A. Keane. 2020. Species and demographic responses to wildlife-friendly fencing on ungulate crossing success and behavior. Conservation Science and Practice 2(10):e285

Sliwinski, M. S., M. E. Burbach, L. A. Powell, and W. H. Schacht. 2018. Factors influencing ranchers' intentions to manage for vegetation heterogeneity and promote cross-boundary management in the northern great plains. Ecology and Society 23(4):45.

Sliwinski, M. S., and N. Koper. 2015. Managing mixed-grass prairies for songbirds using variable cattle stocking rates. Rangeland Ecology and Management 68:470-475. https://doi. org/10.1016/j.rama.2015.07.010

Soil Survey Staff, Natural Resources Conservation Service. Web Soil Survey. United States Department of Agriculture http:// websoilsurvey.sc.egov.usda.gov/

Somershoe, S. 2018. A full annual-cycle conservation strategy for Sprague's Pipit, Chestnut-collared and McCown's Longspurs, and Baird's Sparrow. U.S. Department of the Interior, Fish and Wildlife Service. Washington, DC, USA.

Steuter, A. A., and L. Hidinger. 1999. Comparative ecology of Bison and cattle on mixed-grass prairie. Great Plains Research 9:329-342.

Stevens, B. S., J. W. Connelly, and K. P. Reese. 2012. Multi-scale assessment of greater sage-grouse fence collision as a function of site and broad scale factors. Journal of Wildlife Management 76:1370-1380. https://doi.org/10.1002/jwmg.397

Tack, J. D., A. F. Jakes, P. F. Jones, J. T. Smith, R. E. Newton, B. H. Martin, M. Hebblewhite, and D. E. Naugle. 2019. Beyond protected areas: Private lands and public policy anchor intact pathways for multi-species wildlife migration. Biological Conservation 234:18-27. https://doi.org/10.1016/j.biocon.2019.03.017 
Toombs, T. P., J. D. Derner, D. J. Augustine, B. Krueger, and S. Gallagher. 2010. Managing for biodiversity and livestock. Rangelands 32:10-15. https://doi.org/10.2111/RANGELANDSD-10-00006.1

Truett, J. C., M. Phillips, K. Kunkel, and R. Miller. 2001. Managing bison to restore biodiversity. Great Plains Research 11:123-144.

U.S. Department of the Interior. 2018. Bison Conservation Initiative. U.S. Department of the Interior, Assistant Secretary for Fish and Wildlife and Parks, Washington, DC. https://www. fws.gov/uploadedFiles/BisonConservationInitiative.reduced $\% 20$ size. pdf

Vold, S. T., L. I. Berkeley, and L. B. McNew. 2019. Effects of Livestock Grazing Management on Grassland Birds in a Northern Mixed-Grass Prairie Ecosystem. Rangeland Ecology and Management 72:933-945. https://doi.org/10.1016/j.rama.2019.08.005

White, G. C., and R. E. Bennetts. 1996. Analysis of frequency count data using the negative binomial distribution. Ecology 77:2549-2557. https://doi.org/10.2307/2265753

Williams, E. J., and W. A. Boyle. 2018. Patterns and correlates of within-season breeding dispersal: A common strategy in a declining grassland songbird. The Auk 135:1-14. https://doi. org/10.1642/AUK-17-69.1

Wright, C. K., and M. C. Wimberly. 2013. Recent land use change in the Western Corn Belt threatens grasslands and wetlands. Proceedings of the National Academy of Sciences of the United States of America 110:4134-4139. https://doi.org/10.1073/ pnas. 1215404110

Xian, G., C. Homer, M. Rigge, H. Shi, and D. Meyer. 2015. Characterization of shrubland ecosystem components as continuous fields in the northwest United States. Remote Sensing of Environment 168:286-300. https://doi.org/10.1016/j.rse.2015.07.014

Yang, L., S. Jin, P. Danielson, C. Homer, L. Gass, S. M. Bender, A. Case, C. Costello, J. Dewitz, J. Fry, M. Funk, B. Granneman, G. C. Liknes, M. Rigge, and G. Xian. 2018. A new generation of the United States national land cover database: requirements, research priorities, design, and implementation strategies. ISPRS Journal of Photogrammetry and Remote Sensing 146:108-123. https://doi.org/10.1016/j.isprsjprs.2018.09.006

Editor-in-Chief: Keith A.Hobson Subject Editor: Scott Wilson
Sponsored by the Society of Canadian Ornithologists and Birds Canada

Parrainée par la Société des ornithologistes du Canada et Oiseaux Canada

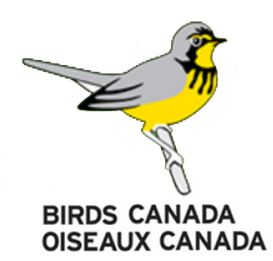


Appendix 1. Estimated abundance of grassland songbird focal species for each 80-ha sampling cell for 2018 and 2019.

\begin{tabular}{|c|c|c|c|c|c|c|c|c|c|c|c|c|c|c|}
\hline cell & year & grazer & BAIS & GRSP & SPPI & LARB & CCLO & LASP & HOLA & SAVS & VESP & MCLO & BRSP & WEME \\
\hline 1076 & 2018 & cow & 0.00 & 0.00 & 0.00 & 6.38 & 7.99 & 0.00 & 11.47 & 0.00 & 0.00 & 0.00 & 42.66 & 15.74 \\
\hline 1076 & 2019 & cow & 0.00 & 0.00 & 0.00 & 10.68 & 0.00 & 0.00 & 69.33 & 8.48 & 51.04 & 0.00 & 143.02 & 26.17 \\
\hline 1243 & 2018 & cow & 0.00 & 0.00 & 0.00 & 19.15 & 0.00 & 0.00 & 11.47 & 0.00 & 3.25 & 0.00 & 10.67 & 13.99 \\
\hline 1243 & 2019 & cow & 0.00 & 0.00 & 0.00 & 7.18 & 0.00 & 0.00 & 32.85 & 0.00 & 3.25 & 0.00 & 51.44 & 13.67 \\
\hline 1391 & 2018 & cow & 0.00 & 0.00 & 0.00 & 0.00 & 3.99 & 0.00 & 20.65 & 0.00 & 8.13 & 0.00 & 53.33 & 13.99 \\
\hline 1392 & 2018 & cow & 0.00 & 15.13 & 0.00 & 2.13 & 0.00 & 0.00 & 16.06 & 0.00 & 9.76 & 0.00 & 21.33 & 19.23 \\
\hline 1392 & 2019 & cow & 0.00 & 18.46 & 0.00 & 10.76 & 0.00 & 0.00 & 26.28 & 4.58 & 11.39 & 0.00 & 22.86 & 10.25 \\
\hline 1553 & 2018 & cow & 0.00 & 0.00 & 0.00 & 2.13 & 0.00 & 0.00 & 13.76 & 0.00 & 1.63 & 0.00 & 26.66 & 20.98 \\
\hline 1600 & 2018 & bison & 12.27 & 37.81 & 0.00 & 0.00 & 19.96 & 0.00 & 11.47 & 10.47 & 4.88 & 0.00 & 21.33 & 22.73 \\
\hline 1878 & 2018 & cow & 0.00 & 0.00 & 0.00 & 116.89 & 0.00 & 0.00 & 50.05 & 0.00 & 13.49 & 0.00 & 0.00 & 21.06 \\
\hline 1878 & 2019 & cow & 0.00 & 0.00 & 0.00 & 5.38 & 0.00 & 0.00 & 32.85 & 0.00 & 16.27 & 0.00 & 17.15 & 10.25 \\
\hline 1921 & 2018 & bison & 0.00 & 52.94 & 0.00 & 0.00 & 0.00 & 0.00 & 4.59 & 0.00 & 3.25 & 0.00 & 16.00 & 27.98 \\
\hline 1922 & 2018 & cow & 0.00 & 30.25 & 0.00 & 0.00 & 0.00 & 0.00 & 9.18 & 0.00 & 6.51 & 0.00 & 21.33 & 19.23 \\
\hline 1922 & 2019 & cow & 0.00 & 36.92 & 0.00 & 0.00 & 0.00 & 0.00 & 19.71 & 0.00 & 19.52 & 0.00 & 34.29 & 20.50 \\
\hline 2027 & 2018 & cow & 0.00 & 22.69 & 0.00 & 0.00 & 15.97 & 0.00 & 6.88 & 6.98 & 13.02 & 0.00 & 16.00 & 24.48 \\
\hline 2027 & 2019 & cow & 0.00 & 92.30 & 0.00 & 0.00 & 0.00 & 0.00 & 13.14 & 13.73 & 8.13 & 0.00 & 34.29 & 18.79 \\
\hline 2146 & 2018 & cow & 0.00 & 0.00 & 0.00 & 23.41 & 3.99 & 0.00 & 25.24 & 0.00 & 6.51 & 0.00 & 10.67 & 22.73 \\
\hline 2146 & 2019 & cow & 0.00 & 0.00 & 0.00 & 28.47 & 0.00 & 0.00 & 69.33 & 0.00 & 25.52 & 0.00 & 28.60 & 33.31 \\
\hline 2197 & 2018 & cow & 0.00 & 0.00 & 0.00 & 132.47 & 0.00 & 0.00 & 0.00 & 0.00 & 6.75 & 0.00 & 31.95 & 25.28 \\
\hline 2254 & 2018 & cow & 0.00 & 0.00 & 0.00 & 19.15 & 3.99 & 0.00 & 11.47 & 0.00 & 8.13 & 0.00 & 74.66 & 12.24 \\
\hline 2334 & 2018 & cow & 10.22 & 60.50 & 5.60 & 0.00 & 55.90 & 0.00 & 6.88 & 6.98 & 0.00 & 0.00 & 0.00 & 12.24 \\
\hline 2334 & 2019 & cow & 54.12 & 163.76 & 10.68 & 0.00 & 86.06 & 0.00 & 0.00 & 16.66 & 0.00 & 0.00 & 0.00 & 11.62 \\
\hline 2648 & 2018 & cow & 18.40 & 45.38 & 5.60 & 0.00 & 39.93 & 0.00 & 0.00 & 10.47 & 0.00 & 0.00 & 0.00 & 8.74 \\
\hline 2648 & 2019 & cow & 38.66 & 93.57 & 10.68 & 0.00 & 86.06 & 0.00 & 0.00 & 38.88 & 0.00 & 0.00 & 0.00 & 29.04 \\
\hline 2673 & 2018 & cow & 0.00 & 0.00 & 0.00 & 155.85 & 0.00 & 0.00 & 100.10 & 0.00 & 26.99 & 0.00 & 53.25 & 21.06 \\
\hline 2845 & 2018 & bison & 0.00 & 168.97 & 0.00 & 15.59 & 0.00 & 0.00 & 16.68 & 0.00 & 40.48 & 0.00 & 31.95 & 46.34 \\
\hline 2846 & 2018 & bison & 2.04 & 68.07 & 0.00 & 14.90 & 0.00 & 0.00 & 0.00 & 0.00 & 6.51 & 0.00 & 0.00 & 19.23 \\
\hline 2847 & 2018 & bison & 0.00 & 68.07 & 0.00 & 6.38 & 0.00 & 0.00 & 11.47 & 0.00 & 9.76 & 0.00 & 0.00 & 27.98 \\
\hline 2847 & 2019 & bison & 0.00 & 74.47 & 69.94 & 0.00 & 0.00 & 0.00 & 0.00 & 0.00 & 31.90 & 0.00 & 0.00 & 35.69 \\
\hline
\end{tabular}




\begin{tabular}{|c|c|c|c|c|c|c|c|c|c|c|c|c|c|c|}
\hline 2881 & 2018 & cow & 0.00 & 42.24 & 0.00 & 116.89 & 0.00 & 27.09 & 116.78 & 0.00 & 13.49 & 0.00 & 0.00 & 46.34 \\
\hline 2947 & 2018 & bison & 0.00 & 22.69 & 0.00 & 0.00 & 0.00 & 0.00 & 0.00 & 0.00 & 8.13 & 0.00 & 5.33 & 15.74 \\
\hline 2947 & 2019 & bison & 0.00 & 92.30 & 0.00 & 1.79 & 0.00 & 0.00 & 0.00 & 0.00 & 13.01 & 0.00 & 22.86 & 22.21 \\
\hline 3133 & 2018 & cow & 0.00 & 126.73 & 0.00 & 0.00 & 54.70 & 18.06 & 16.68 & 0.00 & 40.48 & 0.00 & 31.95 & 54.77 \\
\hline 3133 & 2019 & cow & 15.75 & 0.00 & 19.97 & 0.00 & 0.00 & 0.00 & 0.00 & 0.00 & 9.76 & 0.00 & 0.00 & 17.09 \\
\hline 333 & 2018 & cow & 0.00 & 15.13 & 0.00 & 44.69 & 0.00 & 0.00 & 20.65 & 0.00 & 4.88 & 0.00 & 16.00 & 15.74 \\
\hline 333 & 2019 & cow & 0.00 & 0.00 & 0.00 & 3.59 & 4.13 & 0.00 & 39.42 & 0.00 & 9.76 & 0.00 & 34.29 & 11.96 \\
\hline 3368 & 2018 & cow & 0.00 & 0.00 & 0.00 & 17.02 & 0.00 & 0.00 & 0.00 & 0.00 & 0.00 & 0.00 & 0.00 & 24.48 \\
\hline 3368 & 2019 & cow & 0.00 & 0.00 & 0.00 & 13.37 & 0.00 & 0.00 & 0.00 & 0.00 & 7.42 & 0.00 & 0.00 & 104.69 \\
\hline 3767 & 2018 & cow & 0.00 & 126.73 & 0.00 & 0.00 & 54.70 & 9.03 & 16.68 & 0.00 & 26.99 & 0.00 & 21.30 & 37.91 \\
\hline 3767 & 2019 & cow & 0.00 & 93.57 & 5.34 & 0.00 & 0.00 & 0.00 & 0.00 & 0.00 & 9.21 & 0.00 & 0.00 & 31.94 \\
\hline 3791 & 2018 & cow & 0.00 & 0.00 & 0.00 & 54.55 & 0.00 & 27.09 & 16.68 & 0.00 & 26.99 & 0.00 & 74.55 & 50.55 \\
\hline 3791 & 2019 & cow & 0.00 & 0.00 & 0.00 & 32.06 & 0.00 & 0.00 & 9.85 & 0.00 & 7.32 & 0.00 & 14.29 & 66.11 \\
\hline 3978 & 2018 & cow & 0.00 & 295.70 & 16.62 & 0.00 & 54.70 & 0.00 & 16.68 & 0.00 & 33.73 & 0.00 & 0.00 & 58.98 \\
\hline 3978 & 2019 & cow & 30.92 & 187.15 & 7.12 & 0.00 & 0.00 & 0.00 & 0.00 & 0.00 & 23.03 & 0.00 & 0.00 & 29.04 \\
\hline 4248 & 2018 & bison & 0.00 & 0.00 & 0.00 & 109.10 & 0.00 & 0.00 & 33.37 & 0.00 & 20.24 & 0.00 & 42.60 & 46.34 \\
\hline 4248 & 2019 & bison & 0.00 & 23.39 & 0.00 & 17.15 & 0.00 & 0.00 & 5.41 & 0.00 & 16.12 & 0.00 & 25.72 & 23.23 \\
\hline 4458 & 2018 & bison & 0.00 & 22.69 & 0.00 & 8.51 & 0.00 & 0.00 & 13.76 & 0.00 & 4.88 & 0.00 & 16.00 & 22.73 \\
\hline 4458 & 2019 & bison & 0.00 & 70.18 & 0.00 & 20.58 & 0.00 & 0.00 & 5.41 & 0.00 & 9.21 & 0.00 & 5.14 & 37.75 \\
\hline 4461 & 2018 & bison & 0.00 & 0.00 & 0.00 & 2.13 & 0.00 & 0.00 & 0.00 & 0.00 & 14.64 & 0.00 & 48.00 & 22.73 \\
\hline 4461 & 2019 & bison & 0.00 & 0.00 & 0.00 & 6.86 & 0.00 & 0.00 & 0.00 & 0.00 & 16.12 & 0.00 & 15.43 & 40.66 \\
\hline 4660 & 2018 & bison & 0.00 & 0.00 & 0.00 & 38.96 & 0.00 & 0.00 & 83.41 & 0.00 & 20.24 & 0.00 & 74.55 & 46.34 \\
\hline 4660 & 2019 & bison & 0.00 & 49.65 & 0.00 & 0.00 & 0.00 & 0.00 & 17.33 & 0.00 & 76.56 & 0.00 & 100.12 & 38.07 \\
\hline 4672 & 2018 & bison & 0.00 & 0.00 & 0.00 & 0.00 & 0.00 & 0.00 & 4.59 & 0.00 & 4.88 & 0.00 & 58.66 & 27.98 \\
\hline 4672 & 2019 & bison & 0.00 & 0.00 & 0.00 & 0.00 & 0.00 & 0.00 & 0.00 & 0.00 & 70.18 & 0.00 & 214.54 & 42.83 \\
\hline 4682 & 2018 & cow & 0.00 & 168.97 & 0.00 & 0.00 & 0.00 & 0.00 & 0.00 & 0.00 & 26.99 & 0.00 & 106.50 & 50.55 \\
\hline 4682 & 2019 & cow & 0.00 & 0.00 & 0.00 & 0.00 & 0.00 & 0.00 & 0.00 & 0.00 & 57.42 & 0.00 & 85.81 & 47.58 \\
\hline 4767 & 2018 & bison & 0.00 & 126.73 & 0.00 & 0.00 & 0.00 & 9.03 & 0.00 & 0.00 & 40.48 & 0.00 & 42.60 & 50.55 \\
\hline 4767 & 2019 & bison & 0.00 & 74.47 & 0.00 & 0.00 & 0.00 & 0.00 & 52.00 & 0.00 & 70.18 & 0.00 & 57.21 & 42.83 \\
\hline 4771 & 2018 & bison & 0.00 & 7.56 & 0.00 & 2.13 & 0.00 & 16.23 & 0.00 & 0.00 & 9.76 & 0.00 & 16.00 & 22.73 \\
\hline 4771 & 2019 & bison & 0.00 & 0.00 & 0.00 & 0.00 & 0.00 & 0.00 & 0.00 & 0.00 & 4.88 & 0.00 & 11.43 & 11.96 \\
\hline 510 & 2018 & cow & 0.00 & 0.00 & 0.00 & 0.00 & 11.98 & 0.00 & 2.29 & 0.00 & 1.63 & 0.00 & 21.33 & 19.23 \\
\hline
\end{tabular}




\begin{tabular}{|c|c|c|c|c|c|c|c|c|c|c|c|c|c|c|}
\hline 510 & 2019 & cow & 0.00 & 0.00 & 0.00 & 0.00 & 15.43 & 0.00 & 69.33 & 0.00 & 44.66 & 0.00 & 200.23 & 33.31 \\
\hline 5157 & 2018 & cow & 0.00 & 0.00 & 0.00 & 0.00 & 0.00 & 0.00 & 0.00 & 0.00 & 20.24 & 0.00 & 42.60 & 54.77 \\
\hline 546 & 2018 & cow & 0.00 & 0.00 & 0.00 & 36.18 & 0.00 & 0.00 & 25.24 & 0.00 & 1.63 & 2.75 & 0.00 & 10.49 \\
\hline 546 & 2019 & cow & 0.00 & 0.00 & 0.00 & 0.00 & 0.00 & 0.00 & 26.28 & 0.00 & 13.01 & 0.00 & 5.72 & 3.42 \\
\hline 722 & 2018 & cow & 0.00 & 7.56 & 0.00 & 0.00 & 43.92 & 0.00 & 6.88 & 0.00 & 4.88 & 0.00 & 26.66 & 22.73 \\
\hline 722 & 2019 & cow & 0.00 & 0.00 & 0.00 & 3.56 & 169.72 & 0.00 & 138.65 & 0.00 & 19.14 & 0.00 & 57.21 & 45.21 \\
\hline 831 & 2018 & cow & 0.00 & 0.00 & 0.00 & 0.00 & 3.99 & 0.00 & 4.59 & 0.00 & 6.51 & 0.00 & 32.00 & 19.23 \\
\hline 831 & 2019 & cow & 0.00 & 46.79 & 0.00 & 0.00 & 0.00 & 0.00 & 5.41 & 0.00 & 16.12 & 0.00 & 77.15 & 23.23 \\
\hline Grass01 & 2019 & bison & 92.95 & 148.94 & 17.49 & 0.00 & 231.43 & 0.00 & 34.66 & 0.00 & 6.38 & 0.00 & 0.00 & 35.69 \\
\hline Grass02 & 2019 & bison & 0.00 & 0.00 & 0.00 & 0.00 & 200.58 & 0.00 & 329.30 & 0.00 & 25.52 & 108.33 & 0.00 & 26.17 \\
\hline Grass03 & 2019 & none & 0.00 & 42.68 & 0.00 & 32.04 & 0.00 & 0.00 & 0.00 & 0.00 & 13.39 & 0.00 & 0.00 & 226.34 \\
\hline Grass04 & 2019 & none & 0.00 & 0.00 & 0.00 & 5.34 & 0.00 & 0.00 & 0.00 & 0.00 & 6.70 & 0.00 & 0.00 & 204.79 \\
\hline Grass11 & 2019 & cow & 0.00 & 0.00 & 0.00 & 0.00 & 0.00 & 0.00 & 0.00 & 0.00 & 46.88 & 0.00 & 57.60 & 161.67 \\
\hline Grass12 & 2019 & cow & 0.00 & 18.46 & 0.00 & 0.00 & 0.00 & 542.67 & 0.00 & 0.00 & 4.88 & 0.00 & 45.72 & 17.09 \\
\hline Grass13 & 2019 & cow & 0.00 & 0.00 & 8.74 & 15.43 & 0.00 & 0.00 & 48.18 & 0.00 & 42.88 & 0.00 & 102.37 & 27.08 \\
\hline Grass14 & 2019 & cow & 0.00 & 0.00 & 0.00 & 6.86 & 0.00 & 0.00 & 21.62 & 0.00 & 18.43 & 0.00 & 15.43 & 29.04 \\
\hline Grass16 & 2019 & cow & 52.50 & 55.38 & 89.88 & 0.00 & 12.40 & 0.00 & 6.57 & 9.15 & 0.00 & 0.00 & 0.00 & 15.38 \\
\hline Grass 17 & 2019 & cow & 46.39 & 46.79 & 7.12 & 0.00 & 0.00 & 0.00 & 0.00 & 38.88 & 4.61 & 0.00 & 0.00 & 23.23 \\
\hline Grass 18 & 2019 & cow & 42.00 & 110.76 & 69.91 & 0.00 & 16.54 & 0.00 & 13.14 & 13.73 & 3.25 & 0.00 & 0.00 & \\
\hline Grass19 & 2019 & cow & 0.00 & 24.82 & 0.00 & 0.00 & 46.29 & 0.00 & 138.65 & 0.00 & 63.80 & 0.00 & 71.51 & 45.21 \\
\hline Grass 21 & 2019 & cow & 0.00 & 163.76 & 0.00 & 0.00 & 0.00 & 0.00 & 27.03 & 0.00 & 25.33 & 0.00 & 15.43 & 26.14 \\
\hline Grass 22 & 2019 & bison & 0.00 & 0.00 & 0.00 & 0.00 & 0.00 & 271.33 & 0.00 & 0.00 & 4.88 & 0.00 & 62.87 & 13.67 \\
\hline PD10 & 2019 & bison & 10.50 & 0.00 & 0.00 & 0.00 & 0.00 & 0.00 & 13.14 & 0.00 & 0.00 & 0.00 & 0.00 & 10.25 \\
\hline PD100 & 2019 & bison & 5.25 & 0.00 & 0.00 & 0.00 & 37.21 & 0.00 & 39.42 & 0.00 & 4.88 & 2.09 & 11.43 & 8.54 \\
\hline PD11 & 2019 & cow & 0.00 & 0.00 & 0.00 & 10.29 & 38.25 & 0.00 & 59.46 & 0.00 & 4.61 & 0.00 & 5.14 & 23.23 \\
\hline PD12 & 2019 & cow & 0.00 & 0.00 & 0.00 & 46.26 & 0.00 & 0.00 & 155.99 & 0.00 & 38.28 & 0.00 & 42.91 & 26.17 \\
\hline PD17 & 2019 & cow & 0.00 & 0.00 & 0.00 & 0.00 & 0.00 & 0.00 & 86.66 & 0.00 & 51.04 & 0.00 & 0.00 & 49.96 \\
\hline PD22 & 2019 & bison & 31.76 & 135.23 & 20.39 & 0.00 & 250.88 & 0.00 & 20.96 & 47.97 & 19.26 & 0.00 & 33.94 & 88.93 \\
\hline PD23 & 2019 & bison & 0.00 & 73.04 & 0.89 & 3.43 & 0.00 & 0.00 & 59.55 & 13.89 & 0.00 & 0.00 & 14.30 & 28.01 \\
\hline PD24 & 2019 & cow & 0.00 & 0.00 & 0.00 & 13.35 & 19.12 & 0.00 & 87.56 & 0.00 & 18.00 & 0.00 & 39.09 & 63.64 \\
\hline PD4 & 2019 & bison & 0.00 & 23.39 & 0.00 & 0.00 & 0.00 & 0.00 & 43.24 & 0.00 & 20.73 & 0.00 & 15.43 & 23.23 \\
\hline PD44 & 2019 & bison & 0.00 & 148.94 & 34.97 & 0.00 & 0.00 & 0.00 & 52.00 & 0.00 & 70.18 & 0.00 & 0.00 & 28.55 \\
\hline
\end{tabular}




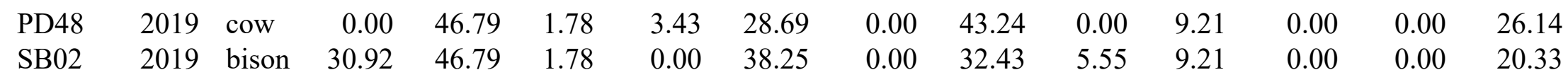

